Kardiyojenik Şok ile Komplike Olmuş ST Yükselmeli Miyokard Enfarktüslü Hastalarda C-reaktif Proteinin Albümin Oranına Prognostik Etkinliği

\title{
Prognostic Efficacy of C-reactive Protein to Albumin Ratio in Patients with ST Elevation Myocardial Infarction Complicated by Cardiogenic Shock
}

Tufan Çınar'1, Veysel Ozan Tanık², Cengiz Burak³, Mahmut Yesin4, Metin Çağdaş4, Yavuz Karabağ4, İbrahim Rencüzoğulları ${ }^{4}$

1Sağlık Bilimleri Üniversitesi, Sultan Abdülhamid Han Eğitim Ve Araştırma Hastanesi, Kardiyoloji Bölümü, Istanbul, Türkiye

2Ankara Dışkapı Yıldırım Beyazıt Eğitim Ve Araştırma Hastanesi, Kardiyoloji Bölümü, Ankara, Türkiye

3Kafkas Üniversitesi Tıp Fakültesi, Kardiyoloji Bölümü, Kars, Türkiye

4Kars Harakani Devlet Hastanesi, Kardiyoloji Kliniği, Kars, Türkiye

\section{$\ddot{O} Z$}

GIRIŞ ve AMAÇ: Bu çalışmada, yakın zamanda geliştirilen enflamasyon dayalı risk indeksi olan C-reaktif proteinin (CRP) IAlbümin oranının (CAR), pompa yetersizliğine bağlı kardiyojenik şok ile komplike olmuş ST yükselmeli miyokard enfarktüs hastalarında (STYME) prognostik bir değere sahip olup olmadığını araştırmayı amaçladık.

YÖNTEM ve GEREÇLER: Primer perkutan koroner girişim uygulanmış ve kardiyojenik şok ile komplike olmuş 79 ardışık STYME hastası geriye dönük olarak çalışmaya alındı.

BULGULAR: Hastane içi takip sirasında 79 hastanın 40'ı (\% 50,6) öldü. Ortalama CAR değeri sağ kalımı olmayanlarda să̆ kalanlarına göre anlamlı derecede yüksekti (8.58 [4.68-12.25] vs. 4.67 [4.21-6.03]; $p<0.001$ ). Çok değişkenli regresyon analizi, CAR'ın hastane içi mortalitenin bağımsız bir belirleyicisi olduğunu ortaya koydu (HR: 1.053, \% 95 CI: 1.006-1.101; $p=0.027$ ). Kaplan-Meier analizi, $C A R \geq 8.4$ olan hastaların ölüm sıklı̆̆l $C A R<8.4$ olanlara göre anlaml derecede yüksek olduğunu gösterdi $(p<0.001)$.

TARTIŞMA ve SONUÇ: Bu çalışma, kardiyojenik şok ile komplike olmuş STYME hastalarında CAR'ın hastane içi mortalite için prognostik bir değere sahip olduğunu gösteren ilk çalışmadır.

Anahtar Kelimeler: C-reaktif protein / albümin oranı, ST yükselmeli miyokard enfarktüsü, kardiyojenik şok.

\begin{abstract}
INTRODUCTION: In this study, we aimed to investigate whether $C$-reactive protein $(C R P)$ to albumin ratio $(C A R)$, recently developed inflammation based risk index, has a prognostic value in patients with ST elevation myocardial infarction (STEMI) complicated by cardiogenic shock due to a pump failure.
\end{abstract}

METHODS: We retrospectively enrolled 79 consecutive STEMI patients who underwent a primary percutaneous coronary intervention and complicated by cardiogenic shock.

RESULTS: During the in-hospital course, 40 of the 79 patients (50.6\%) died. The mean value of CAR was significantly higher in patients with non-survivors than those who survived (8.58 [4.68-12.25] vs. 4.67 [4.21-6.03]; $p<0.001)$. A Cox multivariate regression analyses revealed that the CAR was an independent predictor of the in-hospital mortality (HR: 1.053, 95\% CI: 1.006-1.101; $p=0.027$ ). KaplanMeier analysis showed that the patients with $C A R \geq 8.4$ had a significantly higher the incidence of death compared to those with $C A R<8.4(p<0.001)$.

DISCUSSION and CONCLUSION: The present study is the first to demonstrate that the CAR may have a prognostic value for the in-hospital mortality in patients with STEMI complicated by cardiogenic shock.

Keywords: $C$-reactive protein to albumin ratio, ST elevation myocardial infarction, cardiogenic shock.

Iletişim / Correspondence:

Dr. Tufan Çinar

Sağllk Bilimleri Üniversitesi, Sultan Abdülhamid Han Eğitim Ve Araştırma Hastanesi, Kardiyoloji Bölümü, Istanbul, Türkiye

E-mail: drtufancinar@gmail.com

Başvuru Tarihi: 26.03.2019

Kabul Tarihi: 07.08.2019 


\section{INTRODUCTION}

The effect of inflammation on the development of complications in cardiovascular diseases has been more clearly understood in recent years; hence, the inflammatory biomarkers are now increasingly being used not only for screening but also for prognosis in patients with coronary artery disease (CAD) [1]. Creactive protein (CRP), one of the most commonly used biomarker for this purpose, has been associated with short- and long-term poor prognosis in ST elevation myocardial infarction (STEMI) patients [2-4]. On the other hand, the inflammation may also cause reduction in serum albumin level owing to the reduced synthesis and increased catabolism of it. Previous studies reported that hypoalbuminemia has been associated with the occurrence of myocardial infarction [5] and increased mortality among these patients [6]. Newly introduced inflammation based risk index, CRP/Albumin ratio (CAR), has been demonstrated to better reflect the inflammatory status and prognosis in patients with acute critical conditions and malignancy [7-9]. However, to the best of our knowledge, no previous study has investigated the association between the CAR and STEMI complicated by cardiogenic shock. Therefore, in the present study, we aimed to investigate whether CAR, calculated from the admission blood sample, has a prognostic value in STEMI patients suffered from cardiogenic shock on admission or during the in-hospital course.

\section{MATERIALS and METHODS}

\section{Study population}

Between January 2012 and January 2018, a total of 102 STEMI patients complicated with cardiogenic shock on admission or occurred during in-hospital course were retrospectively screened. The patients with previous history of coronary artery disease (n: 14), known heart failure (n: 2), referred to emergency coronary aorta by-pass grafting (n: 2), and with mechanical complications (n: 5) were excluded from the study (Fig. 1). The remaining 79 patients constituted the study population. The demographic as well as echocardiographic, angiographic, and laboratory data of all patients were obtained from the hospital's electronic database. STEMI was defined based on the following criteria; ongoing ischemic symptoms (within 12 hours), typical rise or fall in the cardiac biomarkers, and a new ST elevation in $\geq 2$ contiguous leads with leads $\mathrm{V} 1, \mathrm{~V} 2$, and V3 measuring $\geq 0.2 \mathrm{mV}$ or $\geq 0.1 \mathrm{mV}$ in the remaining leads or new developed left bundle-branch block pattern [10]. Cardiogenic shock is defined as the presence of signs of hypoperfusion with persistent hypotension (systolic blood pressure $<90 \mathrm{~mm} / \mathrm{Hg}$ ) despite adequate filling status or needing inotropes and/or mechanical support to maintain systolic blood pressure $>90 \mathrm{~mm} / \mathrm{Hg}$. All patients were treated with the standard therapy in accordance with the current guidelines during hospital stay. The study protocol was approved by the Ethics and Research Committee of our hospital, and it was performed according to the Principles of the Declaration of Helsinki. The need for written informed consent was waived due to the retrospective study design.

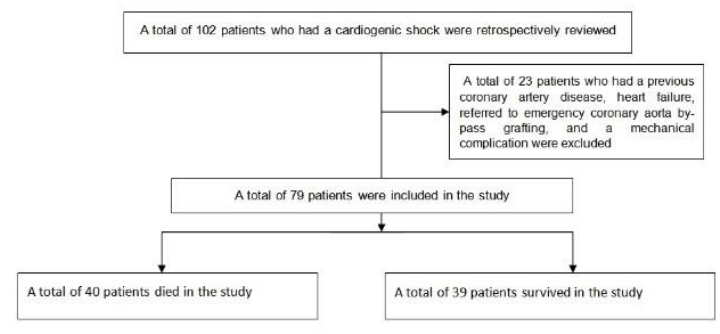

Figure 1 Flow chart of the study participants

2. Coronary angiography and percutaneous coronary intervention

Coronary angiography was performed within 90 minutes via femoral artery in all patients. All patients received an anticoagulation therapy with unfractionated heparin (70-100 units (U)/kg, maximal dose 10.000/U) and dual-antiplatelet therapy with aspirin $(300 \mathrm{mg}$ ) and a loading dose of clopidogrel $(600 \mathrm{mg})$ before the procedure. The culprit lesion was treated with balloon angioplasty and/or stent implantation. The no-reflow was defined as post-procedural thrombolysis in myocardial infarction (TIMI) flow $<3$ or TIMI flow of 3 with myocardial blush grading $<2$. The thrombus burden was assessed according to the TIMI thrombus grading scale that ranged from grade 0 (no thrombus) to grade 5 (very large thrombus causing a vessel occlusion). The patients with grade 5 thrombus were re-classified into grade $0,1,2,3$, or 4 after recanalization with a guide-wire or a small balloon [11]. 


\section{Laboratory analysis and echocardiographic examination}

All blood samples were obtained on admission before the coronary angiography. Troponin I and creatinine kinase-myocardial band (CK-MB) measurements were repeated at six hours' interval until their peak values were achieved. Serum albumin and CRP levels were measured using an automatic biochemical analyzer (Roche Diagonistics Cobas 8000 c502). The CAR was calculated a s the ratio of CRP to albumin level and the neutrophil to lymphocyte ratio (NLR) was calculated as the ratio of the number of neutrophil to lymphocytes, both of which obtained from blood sample upon admission prior to primary percutaneous coronary intervention (pPCI). A nephelometry method was used to measure CRP. In this study, serum albumin level was determined using bromocresolgreen method. The estimated glomerular filtration rate (eGFR) was calculated using the Chronic Kidney Disease Epidemiology Collaboration equation. Transthoracic echocardiography was performed in all patients within 24 hours by using the GE Vivid 5 and 7 system echocardiography machines (GE Vivid 5 and 7; GE Healthcare, Piscataway, New Jersey). Left ventricular ejection fraction (LVEF) of each patient was calculated using biplane the Simpson's method.

\section{Statistical analyses}

Medicalc trial version 16.8.4 (Medicalc Software Bvba, Ostend, Belgium) and SPSS version 22.0 (IBM, Chicago, Illinois) were used to perform statistical analysis. Normality of the data was analyzed using the Kolmogorov-Smirnov test. Continuous variables with normal distribution are expressed as mean ( \pm standard deviation) values and were compared using the Student-t test. Continuous variables without normal distribution are expressed as median (0.25-0.75 percentiles) values and compared using the Mann-Whitney $U$ test. The categorical variables are expressed as numbers (percentages) and were compared using Fisher's exact test or $\chi 2$-test. Event-free survival curves of the CAR tertiles were demonstrated using Kaplan-Meier survival curve analysis and compared using the logrank test. The risk factors for in hospital mortality were analyzed using multivariate Cox proportional hazard analyses with variables that showed statistically significant associations with mortality in the univariate analyses. The receiver operating characteristic (ROC) curve was utilized to derive the best cut-off value of the CAR for predicting all-cause mortality. A $\mathrm{p}$ value $<0.05$ was considered statistically significant.

\section{RESULTS}

The present study retrospectively included 79 STEMI patients in whom presented with cardiogenic shock on admission or occurred during hospital stay. The mean age of study population was $63 \pm 13$ years, 27 patients (34.2\%) were women. During in-hospital course, 40 patients $(50.6 \%)$ died in the cohort. The baseline demographics, clinical, laboratory, and angiographic characteristics of patients died during in-hospital course (n: 40) compared with those survived (n: 39), and it is summarized in Table 1. The results of comparison demonstrated that patients died during in-hospital course had a higher frequency of diabetes mellitus, and the lower rate of smoking than those survived. There were no statistically significant differences in terms of systolic or diastolic blood pressure, heart rate, Killip class $>1$ on admission between the groups. The usage of intra-aortic balloon pump and mechanical ventilation were more common in patients died than those survived. Even though the infarct-related artery, total ischemic time, left main coronary artery disease, and no-reflow were not different between the groups ( $p>0.05$ for each), patients died during inhospital course had a longer door to balloon time, lower LVEF, more frequent multi-vessel ( $\geq 2$ vessel) disease, and proximal or ostial culprit lesion than those survived. In terms of laboratory findings, patients died during in-hospital course had an increased white blood cell count, blood glucose, peak CK-MB and CRP levels, decreased eGFR and serum albumin levels compared to those survived. The median value of CAR was significantly higher in patients with non survivors than those survived (8.58 [4.68-12.25] vs. 4.67 [3.21-6.03]; $p<0.001)$. 
Table 1. Demographic, clinical, laboratory and angiographic characteristics of all patients, patients with and without survival, with P value

\begin{tabular}{|c|c|c|c|c|c|c|c|c|}
\hline \multirow{3}{*}{\multicolumn{2}{|c|}{ Age, year }} & \multicolumn{7}{|c|}{ Patients with cardiogenic shock } \\
\hline & & \multicolumn{2}{|c|}{$\begin{array}{l}\text { All patients } \\
(\mathrm{n}=79)\end{array}$} & \multicolumn{2}{|l|}{$\begin{array}{l}\text { No Death } \\
(\mathrm{n}=39)\end{array}$} & \multicolumn{2}{|c|}{$\begin{array}{l}\text { Death } \\
(\mathrm{n}=40)\end{array}$} & \multirow{2}{*}{$\begin{array}{l}\text { P value } \\
0.259\end{array}$} \\
\hline & & 63.0 & \pm 13.0 & 62.0 & \pm 13.0 & 65.0 & \pm 14.0 & \\
\hline \multicolumn{2}{|c|}{ Female gender, $\mathrm{n}(\%)$} & 27.0 & $(34.2)$ & 12.0 & $(30.8)$ & 15.0 & $(37.5)$ & 0.531 \\
\hline \multicolumn{2}{|c|}{ Diabetes, $\mathrm{n}(\%)$} & 39.0 & $(49.4)$ & 12.0 & $(30.8)$ & 27.0 & $(67.5)$ & 0.001 \\
\hline \multicolumn{2}{|c|}{ Hypertension, n (\%) } & 36.0 & $(45.6)$ & 15.0 & $(38.5)$ & 21.0 & $(52.5)$ & 0.213 \\
\hline \multicolumn{2}{|r|}{ Chronic obstructive lung disease, $\mathrm{n}(\%)$} & 4.0 & $(5.1)$ & 1.0 & $(2.6)$ & 3.0 & $(7.5)$ & 0.320 \\
\hline \multicolumn{2}{|r|}{ Peripheral artery disease, $\mathrm{n}(\%)$} & 29.0 & $(36.7)$ & 12.0 & $(30.8)$ & 17.0 & $(42.5)$ & 0.283 \\
\hline \multicolumn{2}{|c|}{ Dyslipidemia, n (\%) } & 23.0 & $(29.1)$ & 11.0 & $(28.2)$ & 12.0 & $(30.0)$ & 0.862 \\
\hline \multicolumn{2}{|c|}{ Family history of CAD, n (\%) } & 6.0 & (7.6) & 4.0 & $(10.3)$ & 2.0 & $(5.0)$ & 0.381 \\
\hline \multicolumn{2}{|c|}{ Smoking, $\mathrm{n}(\%)$} & 26.0 & (32.9) & 19.0 & $(48.7)$ & 7.0 & $(17.5)$ & 0.003 \\
\hline \multicolumn{2}{|c|}{ Acetylsalicylic acid, n (\%) } & 1.0 & $(1.3)$ & 0.0 & $(0.0)$ & 1.0 & $(2.5)$ & 0.323 \\
\hline \multicolumn{2}{|c|}{$B$-Blocker, n (\%) } & 2.0 & $(2.5)$ & 2.0 & $(5.1)$ & 0.0 & $(0.0)$ & 0.149 \\
\hline \multicolumn{2}{|c|}{ ACEI/ARB, n (\%) } & 12.0 & $(15.2)$ & 7.0 & $(17.9)$ & 5.0 & $(12.5)$ & 0.503 \\
\hline \multicolumn{2}{|c|}{ Statin, n (\%) } & 11.0 & (13.9) & 6.0 & $(15.4)$ & 5.0 & $(12.5)$ & 0.713 \\
\hline \multicolumn{2}{|c|}{ Systolic blood pressure, $\mathrm{mmHg}$} & 72 & \pm 14 & 73 & \pm 15 & 71 & \pm 13 & 0.715 \\
\hline \multicolumn{2}{|r|}{ Diastolic blood pressure, $\mathrm{mmHg}$} & 39 & \pm 10 & 40 & \pm 10 & 38 & \pm 9 & 0.683 \\
\hline \multicolumn{2}{|c|}{ Heart rate, bpm } & 88 & \pm 33 & 90 & \pm 28 & 86 & \pm 37 & 0.918 \\
\hline Kill & lip class > 1 on admission, $\mathrm{n}(\%)$ & 71.0 & $(89.9)$ & 36.0 & $(92.3)$ & 35.0 & $(87.5)$ & 0.482 \\
\hline IAE & $3 \mathrm{P}$ use, $\mathrm{n}(\%)$ & 58.0 & $(73.4)$ & 25.0 & $(64.1)$ & 33.0 & $(82.5)$ & 0.066 \\
\hline $\mathrm{Me}$ & chanical ventilation, n (\%) & 45.0 & $(57.0)$ & 8.0 & $(20.5)$ & 37.0 & $(92.5)$ & $<0.001$ \\
\hline Wh & ite blood cell count, $x 10^{3} / \mathrm{mm}^{3}$ & 17.65 & \pm 5.42 & 15.74 & \pm 3.96 & 19.50 & \pm 6.03 & 0.002 \\
\hline Her & moglobin, $\mathrm{g} / \mathrm{dL}$ & 13.1 & \pm 2.1 & 13.1 & \pm 2.2 & 13.0 & \pm 2.1 & 0.757 \\
\hline Blo & od sugar on admission, $\mathrm{mg} / \mathrm{dL}$ & 189.0 & $136.0-291.0$ & 157.0 & $109.0-232.0$ & 236.0 & $162.5-346.5$ & 0.003 \\
\hline C-R & Reactive protein, mg/dL & 21.75 & $12.40-36.7$ & 18.70 & $11.20-27.30$ & 32.10 & $17.60-43.60$ & 0.016 \\
\hline Ser & um albumin, $\mathrm{g} / \mathrm{dL}$ & 3.39 & \pm 0.72 & 3.59 & \pm 0.8 & 3.19 & \pm 0.58 & 0.019 \\
\hline C-P & Reactive protein/Albumin ratio & 5.38 & $4.03-9.50$ & 4.67 & $3.21-6.03$ & 8.58 & $4.68-12.25$ & $<0.001$ \\
\hline eGI & $\mathrm{FR}, \mathrm{mL} / \mathrm{min} / 1.73 \mathrm{~m}^{2}$ & 65.15 & \pm 31.61 & 75.90 & \pm 31.69 & 54.68 & \pm 28.15 & 0.001 \\
\hline Pea & $\mathrm{k}$ CK-MB, ng/mL & 429.0 & $297.0-636.0$ & 354.0 & $267.0-499.0$ & 465.5 & $329.5-729.0$ & 0.010 \\
\hline Pea & $\mathrm{k}$ troponin I, ng/mL & 265.0 & $156.0-365.0$ & 212.0 & $130.0-314.6$ & 343.5 & 201.4-393.0 & 0.001 \\
\hline Lef & t ventricular ejection fraction, $(\%)$ & 36.9 & \pm 8.0 & 40.5 & \pm 7.4 & 33.4 & \pm 6.9 & $<0.001$ \\
\hline Dor & or to balloon time, min & 37 & \pm 9 & 34 & \pm 6 & 41 & \pm 9 & $<0.001$ \\
\hline Tot & al ischemia time, $\min$ & 240.0 & $140.0-350.0$ & 252.0 & $140.0-390.0$ & 227.50 & $144.5-339.0$ & 0.695 \\
\hline & LAD & 45.0 & $(57.0)$ & 24.0 & $(61.5)$ & 21.0 & $(52.5)$ & 0.371 \\
\hline $\mathrm{R}$ & $\mathrm{Cx}$ & 11.0 & $(13.9)$ & 5.0 & $(12.8)$ & 6.0 & $(15.0)$ & \\
\hline A & RCA & 19.0 & $(24.1)$ & 9.0 & $(23.1)$ & 10.0 & $(25.0)$ & \\
\hline & Other coronaries (Diagonal etc.) & 4.0 & $(5.1)$ & 1.0 & $(2.6)$ & 3.0 & $(7.5)$ & \\
\hline Pro & ximal/ostial lesion for IRA, n (\%) & 70.0 & $(88.6)$ & 31.0 & $(79.5)$ & 39.0 & $(97.5)$ & 0.012 \\
\hline & h-grade thrombus burden, $\mathrm{n}(\%)$ & 66.0 & $(83.5)$ & 30.0 & (76.9) & 36.0 & $(90.0)$ & 0.119 \\
\hline Ste & nt length, mm & 23.38 & \pm 8.82 & 22.53 & \pm 6.90 & 24.18 & \pm 10.36 & 0.609 \\
\hline Ster & nt diameter, mm & 3.08 & \pm 0.37 & 3.03 & \pm 0.34 & 3.14 & \pm 0.39 & 0.321 \\
\hline Cor & rected TIMI frame count & 28 & $23-35$ & 26 & $19-44$ & 28 & $24-35$ & 0.412 \\
\hline No- & -reflow, n (\%) & 20.0 & $(25.3)$ & 12.0 & $(30.8)$ & 8.0 & $(20.0)$ & 0.274 \\
\hline & ICA, n (\%) & 4.0 & $(5.1)$ & 1.0 & $(2.6)$ & 3.0 & $(7.5)$ & 0.320 \\
\hline & of & 29.0 & (36.7) & 20.0 & $(51.3)$ & 9.0 & $(22.5)$ & 0.006 \\
\hline & eased & 33.0 & $(41.8)$ & 14.0 & $(35.9)$ & 19.0 & $(47.5)$ & \\
\hline & $\begin{array}{lll}\text { sels, } & \text { n } & 3\end{array}$ & 17.0 & (21.5) & 5.0 & $(12.8)$ & 12.0 & $(30.0)$ & \\
\hline TIN & MI risk score & 8 & \pm 3 & 7 & \pm 2 & 9 & \pm 2 & $<0.001$ \\
\hline
\end{tabular}


To identify independent predictors of in-hospital mortality, a multivariate Cox regression analyses with a stepwise backward model were performed using the variables that showed marginal association with all-cause mortality in a univariate analysis. These variables were diabetes mel litus, smoking, blood glucose, CAR, eGFR, peak CK-MB, LVEF, and door to balloon time (Table 2). The CAR (hazard ratio $[\mathrm{HR}]: 1.053,95 \%$ confidence interval $[\mathrm{CI}]$ 1.006-1.101; $\mathrm{p}=0.027$ ), eGFR (HR: 0.989, 95\% CI: $0.979-0.999 ; \mathrm{p}=0.049$ ), and door to balloon time (HR: 1.055, 95\% CI: 1.021-1.089; p=0.001) were found to be independent predictors of in-hospital mortality.

\begin{tabular}{|c|c|c|c|c|c|c|}
\hline \multicolumn{7}{|c|}{ Univariate analysis of mortality } \\
\hline & Odds ratio & 95\% C.I. & $P$ value & Odds ratio & 95\% C.I. & $\mathrm{P}$ value \\
\hline C-Reactive protein/Albumin ratio & 1.073 & $1.029-1.120$ & 0.001 & 1.053 & $1.006-1.101$ & 0.027 \\
\hline eGFR & 0.989 & 0.978-0.999 & 0.045 & 0.989 & $0.977-0.999$ & 0.049 \\
\hline Door to balloon time & 1.060 & $1.028-1.092$ & $<0.001$ & 1.055 & $1.021-1.089$ & 0.001 \\
\hline
\end{tabular}

The ROC analysis was used to show the optimal cut-off value of the CAR for predicting in-hospital mortality. The optimal cut-off value of CAR was $\geq 8.4$ with a sensitivity of $47.6 \%$ and a specificity of 91.9\% (area under the curve [AUC]: 0.742; 95\% CI: 0.635-0.849) (Fig. 2). Kaplan-Meier analysis was drawn and showed that patients with CAR <8.4 (n: 56) had a significantly lower incidence of death compared to those with CAR $\geq 8.4$ (n: 23$)(35.7 \%$, n: 20 vs. $87 \%$, n: 20 ; p<0.001) (Fig. 3).

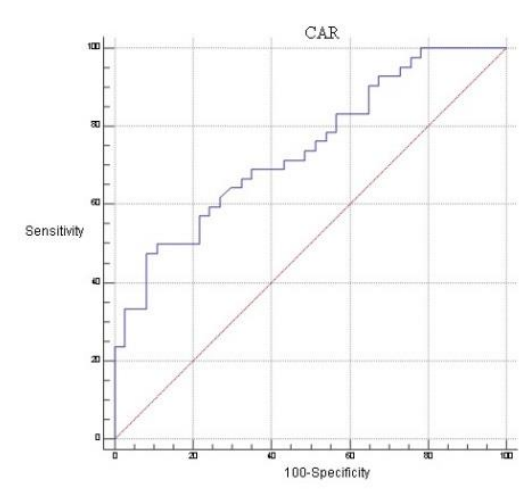

Figure 2. In receiver operating characteristic (ROC) analysis, the optimal cut-off value of the CAR for predicting in-hospital mortality was $\geq 8.4$ with a sensitivity of $47.6 \%$ and a specificity of 91.9\% (area under the curve [AUC]: 0.742; 95\% Cl: 0.635-0.849).

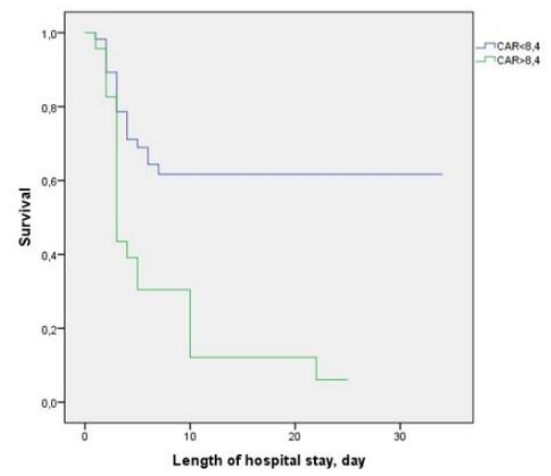

Figure 3. Kaplan-Meier analysis showed that patients with $C A R<8.4$ had a significantly lower incidence of death compared to those with $C A R \geq 8.4$.

\section{DISCUSSION}

The present study demonstrated that the elevated CAR value was associated with in-hospital mortality among STEMI patients who suffered from cardiogenic shock due to the pump failure. The CAR independent predictor of in-hospital mortality.

Cardiogenic shock is a clinical condition of inadequate tissue (end-organ) perfusion due to the inability of the heart to pump an adequate amount of blood. The reduction in tissue perfusion results in decreased oxygen and nutrient delivery to the tissues and, if prolonged, potentially end-organ damage and multi-system failure. Cardiogenic shock is the leading cause of death in patients with acute 
myocardial infarction, and the hospital mortality rates may approach 50\% [12]. In accordance with current knowledge, the mortality rate of our cohort was $50.6 \%$. Al though post-myocardial infarction mechanical complications are important cause of cardiogenic shock, it mainly arises from the pump failure due to severe left ventricular dysfunction. Autopsy studies in patients dying with cardiogenic shock due to acute myocardial infarction have revealed that $40 \%$ or more percent of the LV myocardium had been infarcted (old or new) [13]. In our study, the infarct size was not quantitatively measured, but patients who died had increased door to balloon time, more frequent proximal or ostial lesions as the infarct-related artery, lower LVEF, and higher peak CK-MB values compared to survived patients.

Diabetes mellitus has been known as a major risk factor for coronary artery disease. It has also been established that diabetes mellitus is associated with increased in-hospital mortality in STEMI patients complicated by cardiogenic shock as shown in our study [14]. Chronic kidney disease has been increasingly recognized as an independent risk factor for the development of coronary heart disease. Furthermore, eGFR below $60 \mathrm{ml} / \mathrm{min}$ upon admission is associated with poor short-term prognosis in patients with cardiogenic shock treated with veno-arterial extracorporeal membrane oxygenation [15]. A consisting finding was found as reduced eGFR level was an independent predictor of in-hospital mortality in our cohort.

Besides that being a strong risk factor for development of new cardiovascular events [16, 17]; elevated CRP has been shown to be associated with poor short- and long-term prognosis in STEMI patients [18]. Moreover, it has been established that STEMI patients with cardiogenic shock had a higher CRP levels than those without on admission [2], and elevated levels of CRP has been associated with inhospital and one year mortality among STEMI patients complicated by cardiogenic shock [19]. On the other hand, in contrast to elevation of CRP levels, the inflammatory response of the body might cause hypoalbuminemia via decreasing its synthesis and increasing its degradation. Hypoalbuminemia is found to be related with increased mortality in patients with acute coronary syndrome [20,21]. Furthermore, Oduncu et al. demonstrated that decreased serum albumin level is a strong independent predictor of long-term mortality and development of advanced heart failure in patients with STEMI [6]. In accordance with abovementioned studies, we observed that patients died during in-hospital course had significantly higher CRP and lower serum albumin level than those survived. The inverse relationship between CRP and serum albumin level in response to inflammation has emerged CRP to albumin ratio (CAR). The CAR has been previously studied in patients with acute medical conditions [7, 8] and malignancy [9]; it was observed that an elevated CAR was closely related with poor prognosis. In accordance with these previous findings, we observed that elevated admission CAR values was associated with higher in-hospital mortality in STEMI patients complicated by cardiogenic shock. Serum albumin and CRP levels are not only innocent indices of the inflammation; but also they are active participant in the progression of inflammatory condition. Both serum albumin and CRP levels are associated with endothelial dysfunction and pro-thrombotic state which have a great effect on the progression of cardiogenic shock $(22,23)$.

\section{Limitations of the study}

The certain limitations of the present study need to be acknowledged while interpreting the results of this study. The present study had a retrospective design; therefore, the results might be biased. Second, patients with a previous history of coronary artery disease, with mechanical complication, and referred to emergency $\mathrm{CABG}$ were excluded; thus, these results cannot be generalized to all STEMI patients. Finally, the prognostic value of CAR needs to be validated in further prospective studies.

\section{Conclusion}

To the best of our knowledge, the present study is the first study to demonstrate the prognostic value of CAR in STEMI patients complicated by cardiogenic shock. The elevated CAR on admission was found to be an independent predictor of the in-hospital mortality in patients with STEMI complicated by cardiogenic shock. 


\section{Declaration of Conflicting Interests:}

All authors declare that they do not have conflicts of interests.

\section{Funding:}

The authors received no financial support for the research, authorship, and/or publication of this article.

\section{REFERENCES}

1. Bisoendial RJ, Boekholdt SM, Vergeer M, Stroes ES, Kastelein JJ. C-reactive protein is a mediator of cardiovascular disease. Eur Heart J. 2010; 31:2087-91.

2. Akkus MN, Polat G, Yurtdas M, Akcay B, Ercetin N, Cicek D, et al. Admission levels of Creactive protein and plasminogen activator inhibitor1 in patients with acute myocardial infarction with and without cardiogenic shock or heart failure on admission. Int Hear J. 2009; 50:33-45.

3. Van Diepen S, Newby LK, Lopes RD, Stebbins A, Hasselblad V, James S, et al. Prognostic relevance of baseline pro- and anti-inflammatory markers in STEMI: An APEX AMI substudy. Int $\mathbf{J}$ Cardiol. 2013; 168:2127-33.

4. Brunetti ND, Pellegrino PL, Correale M, De Gennaro L, Cuculo A, Di Biase M. Acute phase proteins and systolic dysfunction in subjects with acute myocardial infarction. $\mathrm{J}$ Thromb Thrombolysis. 2008; 26:196-202.

5. Nelson JJ, Liao D, Sharrett AR, Folsom AR, Chambless LE, Shahar E, et al. Serum albumin level as a predictor of incident coronary heart disease: the Atherosclerosis Risk in Communities (ARIC) study. Am J Epidemiol. 2000; 151:468-77.

6. Oduncu V, Erkol A, Karabay CY, Kurt M, Akgün T, Bulut $\mathrm{M}$, et al. The prognostic value of serum albumin levels on admission in patients with acute ST-segment elevation myocardial infarction undergoing a primary percutaneous coronary intervention. Coron Artery Dis. 2013; 24:88-94.

7. Fairclough E, Cairns E, Hamilton J, Kelly C. Evaluation of a modified early warning system for acute medical admissions and comparison with $\mathrm{C}$ reactive protein/albumin ratio as a predictor of patient outcome. Clin Med. 2009; 9:30-3.
8. Ranzani OT, Zampieri FG, Forte DN, Azevedo LC, Park M. C-Reactive Protein/Albumin Ratio Predicts 90-Day Mortality of Septic Patients. Salluh JIF, editor. PLoS One. 2013; 8:e59321.

9. Kinoshita A, Onoda H, Imai N, Iwaku A, Oishi M, Tanaka K, et al.The C-reactive protein/albumin ratio, a novel inflammation-based prognostic score, predicts outcomes in patients with hepatocellular carcinoma. Ann Surg Oncol. 2015; 22:803-10.

10. Ibanez B, James S, Agewall S, Antunes MJ, Bucciarelli-Ducci C, Bueno H, et al. 2017 ESC Guidelines for the management of acute myocardial infarction in patients presenting with ST-segment elevation: The Task Force for the management of acute myocardial infarction in patients presenting with ST-segment elevation of the European Society of Cardiology (ESC). Eur Heart J. 2018; 39:119-77.

11. Gibson CM, de Lemos JA, Murphy SA, Marble SJ, McCabe $\mathrm{CH}$, Cannon $\mathrm{CP}$, et al. Combination therapy with abciximab reduces angiographically evident thrombus in acute myocardial infarction: a TIMI 14 substudy. Circulation. 2001; 103:2550-4.

12. Fox KA, Steg PG, Eagle KA, Goodman SG, Anderson FA Jr, Granger CB, et al. Decline in rates of death and heart failure in acute coronary syndromes, 1999-2006. JAMA. 2007; 297:18921900.

13. Alonso DR, Scheidt S, Post M, Killip T. Pathophysiology of cardiogenic shock. Quantification of myocardial necrosis, clinical, pathologic and electrocardiographic correlations. Circulation. 1973; 48:588-96.

14. Gąsior M, Pres D, Gierlotka M, Hawranek M, Słonka G, Lekston A, et al.The influence of diabetes on in-hospital and long-term mortality in patients with myocardial infarction complicated by cardiogenic shock: results from the PL-ACS registry. KardiolPol. 2012; 70:1215-24.

15. Kuroki N, Abe D, Iwama T, Sugiyama K, Akashi A, Hamabe Y, et al. Prognostic effect of estimated glomerular filtration rate in patients with cardiogenic shock or cardiac arrest undergoing 
percutaneous veno-arterial extracorporeal membrane oxygenation. J Cardiol. 2016; 68: 439-46.

16. Ridker PM, Buring JE, Shih J, Matias M, Hennekens CH. Prospective Study of C-Reactive Protein and the Risk of Future Cardiovascular Events Among Apparently Healthy Women. Circulation. 1998; 98:731-3.

17. Ridker PM, Cushman M, Stampfer MJ, Tracy RP, Hennekens CH. Inflammation, aspirin, and the risk of cardiovascular disease in apparently healthy men. N Engl J Med. 1997; 336:973-9.

18. Makrygiannis SS, Ampartzidou OS, Zairis MN, Patsourakos NG, Pitsavos C, Tousoulis D, et al. Prognostic usefulness of serial c-reactive protein measurements in st-elevation acute myocardial infarction. Am J Cardiol. 2013; 111:26-30.

19. Lim SY, Jeong MH, Bae EH, Kim W, Kim $\mathrm{JH}$, Hong YJ, et al. Predictive factors of major adverse cardiac events in acute myocardial infarction patients complicated by cardiogenic shock undergoing primary percutaneous coronary intervention. Circ J. 2005; 69:154-8.

20. Kurtul A, Murat SN, Yarlioglues M, Duran M, Ocek AH, Koseoglu C, et al. Usefulness of Serum Albumin Concentration to Predict High Coronary SYNTAX Score and In-Hospital Mortality in Patients With Acute Coronary Syndrome. Angiology. 2016; 67:34-40.

21. Kurtul A, Ocek AH, Murat SN, Yarlioglues M, Demircelik MB, Duran M, et al. Serum albumin levels on admission are associated with angiographic no-reflow after primary percutaneous coronary intervention in patients with ST-segment elevation myocardial infarction. Angiology. 2015; 66:278-85.

22. Bisoendial RJ, Kastelein JJP, Peters SLM, Levels JH, Birjmohun R, Rotmans JI, et al. Effects of CRP infusion on endothelial function and coagulation in normocholesterolemic and hypercholesterolemic subjects. J Lipid Res. 2007; 48:952-60.

23. Purdon AD, Rao AK. Interaction of albumin, arachidonic acid and prostanoids in platelets. Prostaglandins, Leukot Essent Fat Acids. 1989; 35:213-8. 